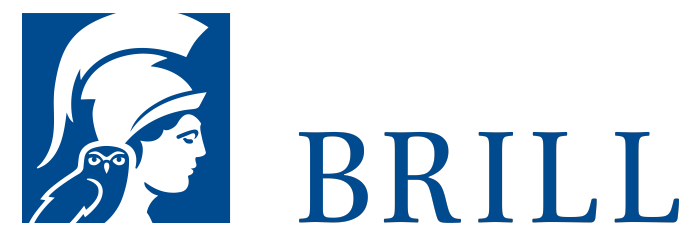

\title{
Gilt das Verbot der Folter absolut?
}

Ethische Probleme polizeilicher Zwangsmaßnahmen zwischen Achtung und Schutz der Menschenwürde

Author: Frank Meier

Gilt das Verbot der Folter absolut? Oder darf der Staat Folter als ultima ratio anwenden, um schwere Verbrechen wie Terroranschläge oder Entführungen zu verhindern? Die zentrale deontologische Begründungsfigur für ein absolutes Folterverbot besteht in dem Verweis auf das Prinzip der Menschenwürde. Im Rahmen dieses Buches wird dieser Begründungsansatz sowohl normenlogisch wie auch inhaltlich analysiert und auf seine Konsistenz hin überprüft. Es zeigt sich, dass in den spezifischen Fallkonstellationen von Rettungsfolterszenarien das Prinzip der Menschenwürde einen deontischen Widerspruch erzeugt, der keine eindeutige Handlungsorientierung bietet. Man kommt nicht umhin einzugestehen, dass sowohl die Realisierung wie auch die Unterlassung von Folter durch dasselbe oberste Prinzip der Menschenwürde geboten wird. Darüber hinaus ist das Dogma einer absoluten Menschenwürde mit den weitgehenden rechtlichen Befugnissen über den Einsatz staatlicher Zwangsmaßnahmen kaum in Einklang zu bringen. In Auseinandersetzung mit Beispielfällen polizeilicher Praxis wird daher ein Stufenmodell der Menschenwürde vorgeschlagen, das eine transparente Entscheidungsfindung im Falle von Würdegegen-Würde-Konflikten ermöglichen soll.

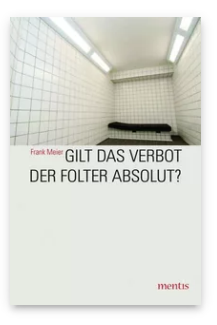

Pages: 208

Seiten

Language:

German

Subjects:

General,

Philosophy

Publisher: Brill | mentis

E-Book (PDF)

Released online:

11 Jan 2016

ISBN: $978-3^{-}$

95743-858-4

List price

Paperback

Publication date:

11 Jan 2016

ISBN: 978-3-

95743-043-4

List price 
For more information see brill.com

Order information: Order online at brill.com +44330 333 0049 | customerservices@brill.com Submission information: brill.com/authors

Titles published by Brill | Fink, Brill | mentis or Brill | Schöningh: +49(o)715413279216| brill@brocom.de 